\title{
Pengaruh Kualitas Website BPS Kab. Siak Terhadap Kepuasan Pengguna Website Menggunakan Metode Webqual 4.0
}

\author{
Nofirman ${ }^{1 *}$, Nizwardi Jalinus ${ }^{2}$, Dedy Irfan ${ }^{3}$ \\ ${ }^{1}$ Aparatur Sipil Negara Kabupaten Siak \\ ${ }^{2,3}$ Program Chief Information Officer, Fakultas Teknik, Universitas Negeri Padang \\ ${ }^{*}$ Corresponding author, e-mail: nofirman1982@gmail.com
}

\begin{abstract}
Abstrak- Penelitian ini bertujuan untuk mengetahui pengaruh kualitas website BPS Kab. Siak terhadap kepuasan pengguna website. Pada penelitian ini kualitas website diukur dengan menggunakan metode webqual. Variabel webqual merupakan variabel bebas yang terdiri dari kemudahan penggunaan, kualitas informasi dan kualitas interaksi layanan. Sedangkan variabel terikatnya adalah kepuasan pengguna. Metode penelitian yang digunakan dalam penelitian ini adalah metode kuantitatif korelasional. Sampel dipilih dari populasi pengguna website BPS Kab. Siak, yang dihitung dengan menggunakan rumus Slovin dengan signifikansi $10 \%$. Untuk menguji pengaruh variabel bebas terhadap variabel terikat menggunakan analisis regresi linier berganda. Penelitian ini menghasilkan pengaruh yang positif dan signifikan dari ketiga variabel bebas terhadap kepuasan pengguna, baik secara parsial maupun secara simultan.
\end{abstract}

Kata Kunci : Webqual, Kepuasan Pengguna, Regresi Linier Berganda

\begin{abstract}
This study aims to determine the influence of website quality of BPS Kab. Siak to the satisfaction of website users. In this study the quality of the website is measured by using webqual method. Webqual variables are independent variables consisting of ease of use, quality of information and quality of service interaction. The dependent variable is user satisfaction. The research method used in this research is quantitative correlation method. Sample selected from population of website user of BPS Kab. Siak, calculated using Slovin formula with $10 \%$ significance. To test the effect of the independent variable on the dependent variable using multiple linear regression analysis. This research resulted in a positive and significant influence of the three independent variables on user satisfaction, either partially or simultaneously.
\end{abstract}

Keywords: Webqual, User Satisfaction, Multiple Linear Regression.

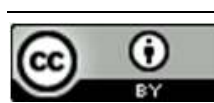

This is an open access article distributed under the Creative Commons 4.0 Attribution License.

\section{Pendahuluan}

Perkembangan TI yang demikian pesat memberikan peluang inovasi produk dan layanan berbasis TI bagi suatu organisasi. Kebutuhan informasi menjadi salah satu faktor penggunaan TI, karena dengan TI kita dapat menghasilkan informasi yang cepat, akurat, dan bisa diakses kapanpun dibutuhkan. Perkembangan TI di Indonesia saat ini tidak hanya dimanfaatkan oleh dunia bisnis dan industri saja, tetapi juga sudah dimanfaatkan oleh instansi pemerintah.

Penggunaaan TI di instansi pemerintahan mutlak harus dilaksanakan sesuai dengan Inpres No.3 Tahun 2003 tentang kebijakan dan strategi nasional pengembangan e-government.
Pengembangan e-government merupakan upaya untuk mengembangkan penyelenggaraan kepemerintahan yang berbasis elektronik dalam rangka meningkatkan kualitas layanan publik secara efektif dan efisien. Pemanfaatan TI mencakup tentang pengolahan data, pengelolaan informasi, sistem manajemen dan proses kerja secara elektronis. Implementasi e-government disetiap organisasi atau instansi tergantung kepada tugas, fungsi, dan wewenang yang diemban oleh setiap lembaga pemerintahan, hal ini juga berlaku pada instansi Badan Pusat Statistik (BPS).

Badan Pusat Statistik (BPS) merupakan Lembaga Pemerintah Non Kementerian yang bertanggung jawab langsung kepada Presiden.

Received 18/08/2018, Revised 24/10/2018, Accepted 14/03/2019 
BPS memiliki tugas sebagai penyedia data dan informasi statistik yang berkualitas, lengkap, akurat, mutakhir, berkelanjutan, dan relevan. Data dan informasi statistik yang disediakan oleh BPS merupakan rujukan bagi pemerintah dalam upaya perumusan kebijakan untuk menyusun perencanaan, melakukan pemantauan dan evaluasi program-program agar sasaran-sasaran yang telah ditetapkan, dicapai dengan tepat, sehingga pembangunan dapat dilaksanakan dengan efektif, efisien dan akuntabel. Selain itu data dan informasi statistik dari BPS juga dibutuhkan oleh sektor swasta, pelajar, mahasiswa dan masyarakat umum untuk perencanaan bisnis, penelitian, tugas kuliah, publikasi dan lain-lain.

Website BPS merupakan aplikasi egovernment yang memliki peranan yang sangat penting dalam menyampaikan data dan informasi statistik bagi pengguna data. BPS memiliki website mulai dari BPS Pusat, BPS Provinsi dan sampai ke tingkat BPS Kabupaten/Kota. Tiap-tiap website BPS menyajikan data dan informasi statistik sesuai dengan tingkat wilayahnya masing-masing.

Salah satu Rencana Strategis BPS tahun 2015-2019 adalah peningkatan kualitas hubungan dengan pengguna data, dengan indikator meningkatnya jumlah pengunjung eksternal website BPS dan meningkatnya kepuasan konsumen akan layanan website BPS[1]. Strategi yang digunakan BPS untuk meningkatkan kualitas hubungan dengan pengguna data adalah dengan cara meningkatkan kualitas dari website BPS.

Analisis mengenai kualitas website BPS khususnya website BPS Kab. Siak dan bagaimana pengaruhnya terhadap kepuasan pengguna website BPS Kab. Siak selama ini belum pernah dilakukan. Sehingga saat ini belum diketahui bukti empiris yang menyatakan kualitas website BPS Kab Siak memiliki pengaruh terhadap kepuasan pengguna website. Berdasarkan hal tersebut maka sangat perlu dilakukan penelitian dengan judul "Pengaruh Kualitas Website BPS Kab. Siak Terhadap Kepuasan Pengguna Website dengan Metode Webqual 4.0 “.

\section{STUdi PUSTAKA}

\subsection{Kualitas}

Menurut Juran [2] kualitas didefenisikan dengan cara sederhana yaitu sebagai kesesuaian untuk digunakan. Lovelock dan
Wright [3] mendefinisikan mengenai kualitas dengan pernyataan berikut: Kualitas meliputi setiap aspek dari suatu perusahaan dan sesungguhnya merupakan suatu pengalaman emosional bagi pelanggan. Pelanggan ingin merasa senang dengan pembelian mereka, merasa bahwa mereka telah mendapatkan nilai terbaik dan ingin memastikan bahwa uang mereka telah dibelanjakan dengan baik, dan mereka merasa bangga akan hubungan mereka dengan sebuah perusahaan yang bercitra mutu tinggi.

Berdasarakan beberapa definisi yang telah diungkapkan oleh para ahli, dapat dinyatakan definisi kualitas ditentukan pada konsumen. Kualitas adalah suatu hal yang diputuskan oleh konsumen, bukan diputuskan oleh penyedia seperti perusahaan atau instansi. Sesuatu yang dibutuhkan atau diharapkan oleh konsumen akan memiliki kualitas jika sesuatu tersebut bisa memenuhi kebutuhan dan harapan konsumen. Kualitas meliputi jasa, produk, manusia, lingkungan dan proses. Kondisi kualitas yang dinamik, sehingga kualitas akan suatu hal untuk saat ini akan bisa berbeda dengan kondisi kualitasnya dimasa mendatang.

\subsection{Kualitas Webite}

Menurut Suyanto [4] kriteria-kriteria website yang baik dapat dilihat dari beberapa faktor yaitu: usability, sistem navigasi, desain visual, konten, compatibility, loading time, functionality, accesibility dan interactivity.

Menurut Hyejeong dan Niehm [5] mengungkapkan bahwa para peneliti terdahulu membagi dimensi kualitas website menjadi lima yaitu:

1. Informasi yang meliputi kualitas konten, kegunaan, kelengkapan, akurat, dan relevan.

2. Keamanan yang meliputi kepercayaan, privasi, dan jaminan keamanan.

3. Kemudahan yang meliputi mudah untuk dioperasikan, mudah dimengerti, dan kecepatan.

4. Kenyamanan yang meliputi daya tarik visual, daya tarik emosional, desain kreatif dan atraktif.

5. Kualitas pelayanan yang meliputi kelengkapan secara online dan customer service.

\subsection{Webqual}

Webqual adalah suatu metode pengukuran kualitas website berdasarkan persepsi 
pengguna akhir. Webqual telah dikembangkan sejak tahun 1998 dan telah mengalami beberapa iterasi dalam penyusunan butir-butir pertanyaannya. Pengembangan webqual telah mencapai versi 4.0. Pada webqual 4.0 disusun berdasarkan pada penelitian tiga area yaitu: kualitas informasi, kualitas interaksi layanan dan kemudahan penggunaan/ usability.

Menurut Barnes dan Vidgen [6] usability merupakan kualitas yang berhubungan dengan desain website dan kemudahan. Jadi terdapat dua subkategori pada kemudahan pengguna yaitu: kemudahan dan desain website. Menurut Barnes dan Vidgen [6] kemudahan dalam webqual 4.0 terdiri dari: kemudahan untuk mempelajari pengoperasian website, interaksi pengguna dengan website jelas dan mudah dipahami, kemudahan dalam bernavigasi, dan kemudahan website untuk digunakan. Menurut Barnes dan Vidgen [6] desain website yang berkualitas adalah memiliki tampilan yang menarik dan menyenangkan, memiliki kompetensi, tampilan sesuai dengan jenis website dan memberikan pengalaman yang positif bagi pengguna website.

Menurut Barnes dan Vidgen [6] kualitas informasi memiliki kategori sebagai berukut:

1. Akurat.

2. Dipercaya.

3. Tepat waktu.

4. Relevan.

5. Mudah dipahami.

6. Lengkap dan detail.

7. Memiliki format yang tepat.

Kualitas interaksi layanan merupakan mutu interaksi pelayanan yang dialami oleh pengguna ketika mereka menyelidiki kedalam website secara lebih dalam sehingga terwujud kepercayaan dan empati terhadap website. Jadi terdapat dua subkategori pada kualitas interaksi layanan yaitu: kepercayaan dan empati.

Menurut Barnes dan Vidgen [6] interaksi layanan yang menimbulkan kepercayaan bagi pengguna layanan dengan cara:

1. Website memiliki reputasi yang baik.

2. Rasa aman untuk menyelesaikan transaksi.

3. Rasa aman akan informasi yang bersifat pribadi.

4. Percaya bahwa barang/jasa akan diterima sesuai janji.

Menurut Barnes dan Vidgen [6] interaksi layanan yang berkualitas sehingga terwujudnya empati adalah dengan cara menciptakan rasa personalisasi bagi pengguna, memberikan ruang berkomunikasi antar sesama pengguna website, memberi kemudahan untuk berkomunikasi dengan penyedia layanan.

\subsection{Kepuasan Pengguna}

Saat ini kepuasan konsumen merupakan hal penting, baik bagi perusahaan yang bergerak dalam bidang barang/jasa maupun bagi instansi pemerintahan dalam memberikan pelayanan terhadap masyarakat. Makanya sering kita dengar slogan yang menyatakan bahwa konsumen adalah raja, ini tentunya tidak lepas dari upaya untuk meningkatkan kepuasan konsumen. Konsumen dari website BPS Kab.Siak tentunya merupakan pengguna website tersebut.

Menurut Kotler [7] kepuasan adalah perasaan senang atau kecewa seseorang yang muncul setelah membandingkan antara persepsi atau kesan terhadap kinerja atau hasil suatu produk dengan harapan-harapannya.

Westbrook \& Reilly dalam Tjiptono [8] mengemukakan bahwa kepuasan konsumen merupakan respon emosional terhadap pengalaman yang berkaitan dengan produk atau jasa yang didapatkan.

Berdasarkan beberapa defini kepuasan dapat disimpulkan bahwa kepuasan pengguna website BPS Kab.Siak adalah perasaan yang dirasakan oleh pengguna website setelah membandingkan layanan yang didapatkannya dari website dengan harapan atau keinginannya terhadap layanan website.

Menurut Irawan [9] faktor - faktor yang pendorong kepuasan pelanggan adalah sebagai berikut:

1. Kualitas produk.

Pelanggan puas kalau setelah membeli dan menggunakan produk tersebut ternyata kualitas produknya baik.

2. Harga.

Untuk pelanggan yang sensitive, biasanya harga murah adalah sumber kepuasan yang penting karena pelanggan akan mendapatkan value for money yang tinggi.

3. Service quality.

Kepuasan terhadap kualitas pelayanan merupakan sesuatu yang biasanya sulit ditiru.

\section{Emotional Factor.}


Pelanggan akan merasa puas dan bangga karena adanya emosional value yang diberikan oleh brand dari produk tersebut.

5. Biaya dan kemudahan.

Pelanggan akan semakin puas apabila relatif mudah, nyaman dan efisien dalam mendapatkan produk atau pelayanan.

Kotler [10] menyatakan ciri-ciri konsumen yang merasa puas sebagai berikut:

1. Loyal terhadap produk

Konsumen yang puas cenderung loyal dimana mereka akan membeli ulang dari produsen yang sama.

2. Adanya komunikasi dari mulut ke mulut yang bersifat positif.

Komunikasi dari mulut ke mulut (word of mouth communication) yang bersifat positif yaitu rekomendasi kepada calon konsumen lain dan mengatakan hal-hal yang baik mengenai produk dan perusahaan.

3. Perusahaan menjadi pertimbangan utama ketika membeli produk lain.

Ketika konsumen ingin membeli produk yang lain, maka perusahaan yang telah memberikan kepuasan kepadanya akan menjadi pertimbangan yang utama.

\section{METODE}

Metode yang digunakan dalam penelitian ini adalah metode kuantitatif korelasional. Populasi dalam penelitian ini adalah pengguna website BPS Kab. Siak selama bulan Januari 2018 s/d Februari 2018. Pengambilan sampel pada penelitian ini menggunakan metode nonprobability sampling. Dengan menggunakan rumus Slovin didapatkan sampel minimal sebanyak 91 responden.

Variabel yang digunakan dalam penelitian ini dibedakan menjadi dua kategori yaitu variabel bebas $(\mathrm{X})$ dan variabel terikat $(\mathrm{Y})$. Adapun yang termasuk dalam variabel bebas (X) pada penelitian ini adalah: Kemudahan Penggunaan (X1), Kualitas Informasi (X2) dan Kualitas Interaksi Layanan (X3). Variabel terikat (Y) dalam penelitian ini adalah Kepuasan Pengguna (Y).

Untuk menghasilkan gambaran umum tentang variabel-variabel yang diteliti maka dilakukan analisis deskriptif. Pada penelitian ini analisis deskriptif menggunakan rumus derajat pencapaian.

Sebelum dilakukan uji hipotesis dengan analisis regresi berganda, maka perlu dilakukan uji asumsi klasik terlebih dahulu, agar data sampel yang diolah benar-benar dapat mewakili populasi secara keseluruhan. . Uji asumsi klasik terdiri dari uji linieritas, uji normalitas, uji multikolinieritas dan uji heterokedastisitas. Setelah persyaratan uji asumsi klasik terpenuhi, maka selanjutnya dilakukan uji hipotesis. Untuk hipotesis pertama, kedua dan ketiga di uji dengan menggunakan uji t, sedangkan hipotesis ke empat di uji dengan uji F.

Untuk melihat pengaruh secara keseluruhan dari variabel bebas terhadap variabel terikat dapat dilihat dari koefisien dterminasi. Sedangkan untuk mengetahui pengaruh masing-masing variabel bebas terhadap variabel terikat dapat diketahui dengan menghitung sumbangan efektif untuk tiap-tiap variabel bebas.

\section{HASIl DAN PEMbahasan}

\subsection{Analisis Deskriptif}

Berdasarkan hasil penghitungan derajat pencapaian diperoleh derajat pencapaian untuk tiap variabel dapat dilihat pada tabel 1 .

Tabel 1. Rangkuman Derajat Pencapaian Variabel Penelitian

\begin{tabular}{|l|c|c|}
\hline \multicolumn{1}{|c|}{ Variabel } & $\begin{array}{c}\text { Derajat } \\
\text { Pencapaian } \\
(\%)\end{array}$ & Kategori \\
\hline $\begin{array}{l}\text { Kemudahan } \\
\text { Penggunaan }\end{array}$ & 65,01 & Cukup \\
\hline $\begin{array}{l}\text { Kualitas } \\
\text { Informasi }\end{array}$ & 66,85 & Cukup \\
\hline $\begin{array}{l}\text { Kualitas } \\
\text { Interaksi } \\
\text { Layanan }\end{array}$ & 65,15 & Cukup \\
\hline $\begin{array}{l}\text { Kepuasan } \\
\text { Pengguna }\end{array}$ & 68,10 & Cukup \\
\hline
\end{tabular}

Dari data diketahui bahwa semua variabel dalam penelitian ini mempunyai nilai derajat pencapaian yang termasuk dalam kategori cukup.

\subsection{Uji Persyaratan Analisis}

Sudjana [11] menyatakan bahwa persyaratan-persyaratan yang harus dipenuhi untuk penggunaan teknik analisis korelasi dan 
regresi adalah (a) garis hubungan antara variabel bebas dengan variabel terikat membentuk garis linier (b) data berasal dari populasi yang berdistribusi normal, (c) kelompok populasi mempunyai varians yang homogen, (d) antar variabel bebas tidak berkorelasi secara signifikan (independen).

\section{a. Uji Linieritas}

Pada Tabel 2, diketahui nilai signifikansi linearity untuak tiap variabel bebas adalah 0,00 $<0,05$ dan nilai signifikansi deviation from linearity untuk tiap variabel bebas $>0,05$, dengan demikian antara variabel kepuasan pengguna (Y) mempunyai hubungan yang linear dengan masing-masing variabel bebas.

Tabel 2. Rangkuman Hasil Uji Linieritas

\begin{tabular}{|c|c|c|c|}
\hline Variabel & $\begin{array}{c}\text { Line } \\
\text { arity }\end{array}$ & $\begin{array}{c}\text { Deviation } \\
\text { From } \\
\text { Linearity }\end{array}$ & Ket \\
\hline X1 dengan $Y$ & 0,00 & 0,234 & Linier \\
\hline X2 dengan $Y$ & 0,00 & 0,062 & Linier \\
\hline X3 dengan $Y$ & 0,00 & 0,074 & Linier \\
\hline
\end{tabular}

\section{b. Uji Normalitas}

Pada Tabel 3 diketahui nilai bahwa nilai Asymp.Sig.(2-tailed) sebesar 0,200 $>0,05$, sehingga dapat disimpulkan bahwa data yang kita uji berdistribusi normal.

Tabel 3. Hasil Uji Normalitas Data Dengan Kolmogorov Smirnov

\begin{tabular}{|c|c|c|}
\hline & $\begin{array}{c}\text { Unstandardized } \\
\text { Residual }\end{array}$ \\
\hline \multicolumn{2}{|l|}{$\mathrm{N}$} & 96 \\
\hline \multirow{2}{*}{$\begin{array}{l}\text { Normal } \\
\text { Parameters }^{\mathrm{a}, \mathrm{b}} \\
\end{array}$} & Mean & 0,0000000 \\
\hline & Std. Deviation & 2,40356652 \\
\hline \multirow{3}{*}{$\begin{array}{l}\text { Most Extreme } \\
\text { Differences }\end{array}$} & Absolute & 0,045 \\
\hline & Positive & 0,045 \\
\hline & Negative & $-0,040$ \\
\hline \multicolumn{2}{|l|}{ Test Statistic } & 0,045 \\
\hline \multicolumn{2}{|c|}{ Asymp. Sig. (2-tailed) } & $\mathbf{0 , 2 0 0}$ \\
\hline
\end{tabular}

Selain dengan melihat nilai signifikan, uji normalitas juga dapat dilakukan dengan melihat histogram dan grafik P-P Plot of Regression Standarized Residual. Berdasarkan Gambar 1 terlihat jumlah titik/ spot yang ditampilkan berjumlah 96 titik yang mendekati garis diagonal dan menyebar mengikuti arah garis diagonal. Hal ini menunjukkan bahwa data terdistribusi normal.

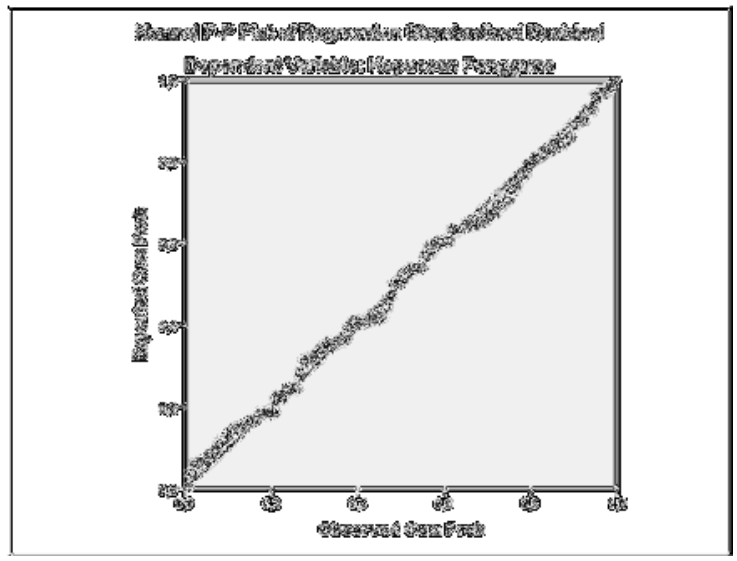

Gambar 1. Grafik P-P Plots Uji Normalitas

Pada Gambar 2 menunjukkan bahwa pada grafik histogram terdapat adanya pola distribusi normal, dimana grafik mengikuti arah kurna normal. Hal ini menunjukkan bahwa data terdistribusi normal.

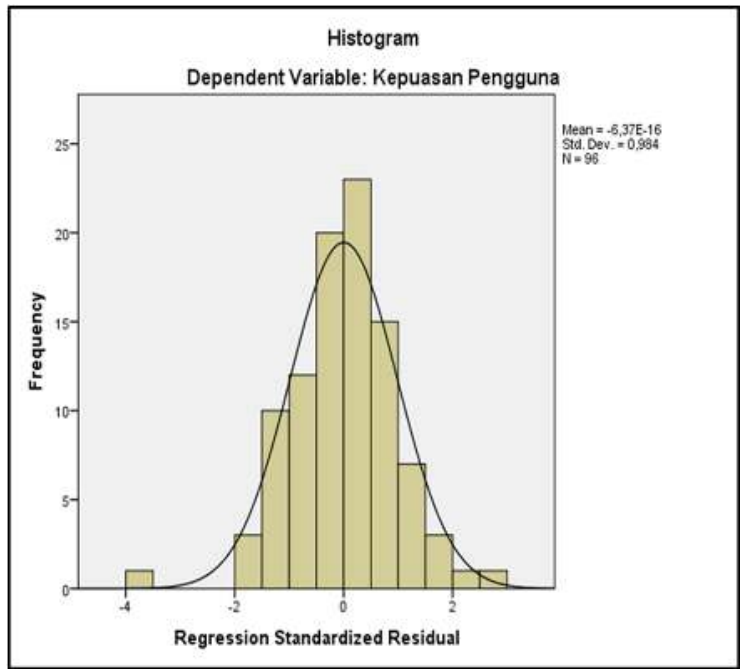

Gambar 2. Histogram Uji Normalitas

\section{c. Uji Multikolinearitas}

Berdasarkan Tabel 4 diketahui tidak terdapat multikolinearitas yang berarti antara masing-masing variabel independen dalam model regresi, karena nilai toleransi lebih besar dari 0,10 dan nilai VIF lebih kecil dari 10,00.

Tabel 4. Hasil Uji Multikolinearitas

\begin{tabular}{|l|l|l|l|}
\hline \multicolumn{2}{|c|}{ Model } & \multicolumn{2}{c|}{ Collinearity Statistics } \\
\cline { 3 - 4 } & Tolerance & VIF \\
\hline 1 & (Constant) & & \\
\hline
\end{tabular}




\begin{tabular}{|l|c|c|c|}
\hline $\begin{array}{l}\text { Kemudahan } \\
\text { Penggunaan }\end{array}$ & 0,782 & 1,279 \\
\hline $\begin{array}{l}\text { Kualitas } \\
\text { Informasi }\end{array}$ & 0,716 & 1,396 \\
\hline $\begin{array}{l}\text { Kualitas Interaksi } \\
\text { Layanan }\end{array}$ & 0,740 & 1,352 \\
\hline
\end{tabular}

\section{d. Uji Heterokedastisitas}

Hasil uji heteroskedastisitas pada Gambar 3 menunjukkan bahwa titik-titik tersebar diatas dan dibawa angka nol. Titik-titik menyebar dan tidak membentuk pola tertentu yang teratur sehingga dapat disimpulkan bahwa dalam model regresi tidak terjadi heteroskedastisitas.

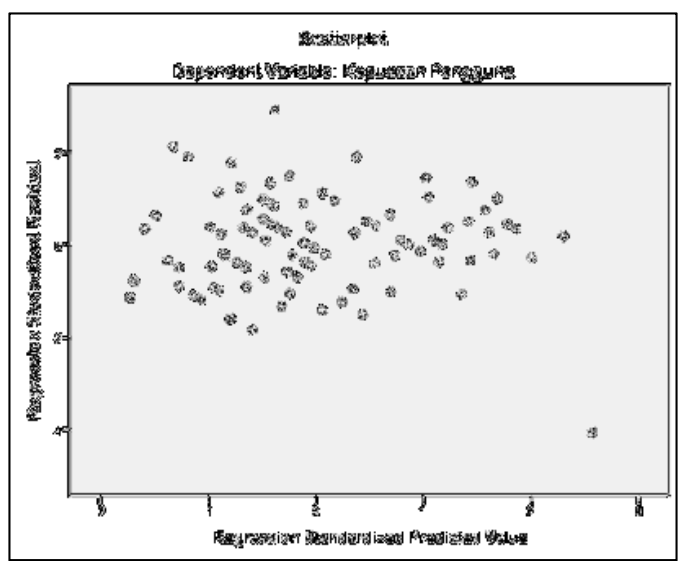

Gambar 3. Scatterplot Heterokedastisitas Variabel Penelitian

\subsection{Hasil Uji Hipotesis}

\section{a. Uji t}

Uji t dilakukan untuk menguji hipotesis pertama, hipotesis kedua dan hipotesis ketiga. Berdasarkan hasil analisis pada Tabel 5 menunjukkan bahwa nilai t hitung untuk tiap variabel bebas lebih besar dari t tabel $(1,986)$ sedangkan nilai Sig. untuk tiap variabel bebas nilainya lebih kecil dari 0,05 . Artinya hipotesis 1,2 dan 3 diterima, dengan demikian variabel kemudahan penggunaan, kualitas informasi dan kualitas interaksi layanan secara parsial berpengaruh secara signifikan terhadap kepuasan pengguna.

Berdasarkan hasil analisis pada Tabel 6 menunjukkan bahwa nilai $\mathrm{F}$ hitung sebesar 54,126 yang nilainya lebih besar dari $\mathrm{F}$ tabel $(2,7)$ sedangkan nilai signifikan untuk pengaruh variabel independen secara bersama- sama terhadap variabel dependen adalah 0,000 yang nilainya lebih kecil dari 0,05 . Hasil ini menunjukkan Ho ditolak dan menerima $\mathrm{H} 4$ yaitu terdapat pengaruh signifikan antara Kemudahan Penggunaan, Kualitas Informasi dan Kualitas Interaksi Layanan secara bersama-sama terhadap Kepuasan Pengguna website BPS Kab. Siak.

Tabel 5. Hasil Uji Koefisien Regresi

\begin{tabular}{|c|c|c|c|c|c|c|}
\hline \multicolumn{7}{|c|}{ Coefficients $^{\mathrm{a}}$} \\
\hline & \multirow{2}{*}{ Model } & \multicolumn{2}{|c|}{$\begin{array}{c}\text { Unstandardized } \\
\text { Coefficients }\end{array}$} & \multirow{2}{*}{$\begin{array}{c}\begin{array}{c}\text { Standardized } \\
\text { Coefficients }\end{array} \\
\text { Beta } \\
\end{array}$} & \multirow[b]{2}{*}{$\mathrm{t}$} & \multirow[b]{2}{*}{ Sig. } \\
\hline & & B & $\begin{array}{l}\text { Std. } \\
\text { Error }\end{array}$ & & & \\
\hline \multirow[t]{4}{*}{1} & (Constant) & 0,214 & 2,190 & & 0,098 & 0,923 \\
\hline & $\begin{array}{l}\text { Kemudahan } \\
\text { Penggunaan }\end{array}$ & 0,218 & 0,031 & 0,495 & 6,984 & $\mathbf{0 , 0 0 0}$ \\
\hline & $\begin{array}{l}\text { Kualitas } \\
\text { Informasi }\end{array}$ & 0,257 & 0,059 & 0,325 & 4,390 & $\mathbf{0 , 0 0 0}$ \\
\hline & $\begin{array}{l}\text { Kualitas } \\
\text { Interaksi } \\
\text { Layanan }\end{array}$ & 0,168 & 0,069 & 0,178 & 2,446 & 0,016 \\
\hline
\end{tabular}

\section{b. Uji F}

Uji $F$ dilakukan untuk menguji hipotesis keempat

Tabel 6. Hasil Analisis Koefisien F

\begin{tabular}{|c|l|c|c|c|c|c|}
\hline \multicolumn{7}{|c|}{ ANOVA $^{\text {a }}$} \\
\hline \multicolumn{2}{|c|}{ Model } & $\begin{array}{c}\text { Sum of } \\
\text { Squares }\end{array}$ & df & $\begin{array}{c}\text { Mean } \\
\text { Square }\end{array}$ & F & Sig. \\
\hline \multirow{4}{*}{1} & Regression & 968,662 & 3 & 322,887 & 54,126 & 0,000 \\
\cline { 2 - 8 } & Residual & 548,828 & 92 & 5,966 & & \\
\cline { 2 - 8 } & Total & 1517,490 & 95 & & & \\
\hline
\end{tabular}

\section{c. Koefisien Determinasi}

Pada tabel 7 diperoleh nilai korelasi (r) variabel bebas secara bersama-sama sebesar 0,799 . Nilai koefesien determinasi atau $R$ square adalah sebesar 0,638 yang mengandung pengertian bahwa pengaruh variabel Kemudahan Penggunaan (X1), Kualitas Informasi (X2) dan Kualitas Interaksi Layanan (X3) secara bersama-sama terhadap Kepuasan Pengguna (Y) sebesar 63,8\% sedangkan sisanya $36,2 \%$ dipengaruhi oleh variabel lain diluar persamaan regresi.

\section{d. Sumbangan Efektif}

Untuk mengetahui seberapa besar pengaruh masing-masing variabel bebas terhadap 
variabel kepuasan penggguna, dihitung dengan mencari sumbangan efektif untuk tiap variabel bebas. Hasil perhitungan sumbangan efektif dapat dilihat pada tabel 8 .

Tabel 7. Koefisien Determinasi (R2) variabel $\mathrm{X} 1, \mathrm{X} 2, \mathrm{X} 3$ terhadap Y

\begin{tabular}{|c|c|c|c|c|}
\hline \multicolumn{5}{|c|}{ Model Summary } \\
\hline Model & $\mathrm{R}$ & $\begin{array}{c}\mathrm{R} \\
\text { Square }\end{array}$ & $\begin{array}{c}\text { Adjusted } \\
\text { R Square }\end{array}$ & $\begin{array}{c}\text { Std. Error of } \\
\text { the Estimate }\end{array}$ \\
\hline 1 & 0,799 & 0,638 & 0,627 & 2,44244 \\
\hline $\begin{array}{l}\text { a. Predictors: (Constant), Kualitas Interaksi } \\
\text { Layanan, Kemudahan Penggunaan, Kualitas } \\
\text { Informasi }\end{array}$
\end{tabular}

Tabel 8. Sumbangan Efektif Variabel Independen

\begin{tabular}{|c|c|c|c|}
\hline Variabel Bebas & Beta & \begin{tabular}{|c|} 
Pearson \\
Correlation
\end{tabular} & SE $(\%)$ \\
\hline \begin{tabular}{|l|} 
Kemudahan \\
Penggunaan
\end{tabular} & 0,495 & 0,699 & 34,6 \\
\hline Kualitas Informasi & 0,325 & 0,614 & 20 \\
\hline $\begin{array}{l}\text { Kualitas Interaksi } \\
\text { Layanan }\end{array}$ & 0,178 & 0,519 & 9,2 \\
\hline \multicolumn{3}{|c|}{ TOTAL } & 63,8 \\
\hline
\end{tabular}

\subsection{Pembahasan}

\section{a) Pengaruh Kemudahan Penggunaan terhadap Kepuasan Penggunaan Website BPS Kab. Siak}

Hasil Uji t untuk variabel kemudahan penggunaan diperoleh nilai t hitung sebesar 6,984 yang nilainya lebih besar dari t tabel $(1,986)$ dan nilai signifikan $0,000<0,05$ artinya variabel kemudahan penggunaan memiliki pengaruh signifikan terhadap kepuasan pengguna. Nilai koefisien regresi variabel kemudahan penggunaan bernilai positif yaitu sebesar 0,218 , artinya terjadi hubungan yang positif antara kemudahan penggunaan dan kepuasan pengguna website BPS Kab. Siak. Sehingga dapat diperoleh hasil variabel kemudahan penggunaan berpengaruh positif dan signifikan terhadap kepuasan pengguna website BPS Kab. Siak. Berdasarkan perhitungan sumbangan efektif, variabel kemudahan penggunaan berkontribusi sebesar $34,60 \%$ terhadap kepuasan pengguna website BPS Kab. Siak. Nilai sumbangan efektif untuk variabel kemudahan penggunaan ini merupakan nilai yang terbesar diantara variabel bebas lainnya dalam penelitian ini.

Variabel kemudahaan penggunaan terdiri dari dua indikator yaitu kemudahan dan desain. Untuk indikator kemudahan diperoleh nilai derajat pencapaian sebesar $65,12 \%$. Nilai ini berada pada kategori cukup. Untuk indikator desain, diperoleh derajat pencapaian sebesar $64,72 \%$. Nilai ini berada pada kategori kurang. Meningkatkan kemudahan dan desain website BPS Kab. Siak maka akan maningkatkan kepuasan pengguna website.

\section{b) Pengaruh Kualitas Informasi terhadap Kepuasan Pengguna}

Hasil Uji t untuk variabel kualitas informasi diperoleh nilai t hitung sebesar 4,390 yang nilainya lebih besar dari t tabel $(1,986)$ dan nilai signifikan $0,000<0,05$ artinya variabel kualitas informasi memiliki pengaruh signifikan terhadap kepuasan pengguna. Nilai koefisien regresi variabel kualitas informasi bernilai positif yaitu sebesar 0,257 , artinya terjadi hubungan yang positif antara kualitas informasi dan kepuasan pengguna website BPS Kab. Siak. Sehingga dapat diperoleh hasil bahwa variabel kualitas informasi berpengaruh positif dan signifikan terhadap kepuasan pengguna website BPS Kab. Siak. Dengan diterimanya hipotesis kedua, maka untuk meningkatkan kepuasan pengguna dari website BPS Kab. Siak maka dapat dilakukan dengan meningkatkan kualitas informasi. Berdasarkan perhitungan sumbangan efektif, variabel kualitas informasi berkontribusi sebesar 20\% terhadap kepuasan pengguna website BPS Kab. Siak.

Variabel kualitas informasi terdiri dari tiga indikator yaitu waktu, isi dan bentuk. Untuk indikator waktu diperoleh nilai derajat pencapaian sebesar $64,17 \%$ dengan kategori kurang. Indikator isi memiliki nilai derajat pencapaiannya sebesar $67,03 \%$ dengan kategori cukup. bahwa derajat pencapaian untuk indikator bentuk dari informasi sebesar $69,17 \%$ dan berada pada kategori cukup.

Meningkatkan kualitas isi, waktu dan bentuk dari informasi yang disajikan pada website BPS Kab. Siak, maka kepuasan pengguna website juga akan mengalami peningkatan. 
c) Pengaruh Kualitas Interaksi Layanan terhadap Kepuasan Pengguna

Hasil Uji t untuk variabel kualitas interaksi layanan diperoleh nilai t hitung sebesar 2,446 yang nilainya lebih besar dari $\mathrm{t}$ tabel $(1,986)$ dan nilai signifikan $0,000<0,05$ artinya variabel kualitas interaksi layanan memiliki pengaruh signifikan terhadap kepuasan pengguna. Nilai koefisien regresi variabel kualitas interaksi layanan bernilai positif yaitu sebesar 0,168 , artinya terjadi hubungan yang positif antara kualitas interaksi layanan dan kepuasan pengguna website BPS Kab. Siak. Sehingga dapat diperoleh hasil bahwa variabel kualitas interaksi layanan berpengaruh positif dan signifikan terhadap kepuasan pengguna website BPS Kab. Siak. Dengan diterimanya hipotesis ketiga, maka untuk meningkatkan kepuasan pengguna dari website BPS Kab. Siak maka dapat dilakukan dengan meningkatkan kualitas interaksi layanan. Berdasarkan perhitungan sumbangan efektif, variabel kualitas interaksi layanan berkontribusi sebesar 9,2\% terhadap kepuasan pengguna website BPS Kab. Siak. Nilai sumbangan efektif untuk variabel kualitas interaksi layanan ini merupakan yang terendah dibandingkan variabel bebas lainnya. Tentunya kualitas interaksi layanan in sangat perlu diperbaiki demi peningkatan kepuasan pengguna website BPS Kab. Siak.

Hasil penelitian ini menunjukkan bahwa derajat pencapaian untuk variabel kualitas interaksi layanan sebesar $65,15 \%$. Nilai derajat pencapaian ini berada kategori cukup, bahkan mendekati kurang. Variabel kualitas interaksi layanan terdiri dari dua indikator yaitu kepercayaan dan empati. Untuk indikator kepercayaan memiliki derajat pencapaian $64,5 \%$ dan berada pada kategori kurang. Pengguna website BPS kab. Siak merasa kurang baik akan reputasi website, kemanan data pribadi, kepercayaan akan kesesuaian file yang didownload. Untuk indikator empati memiliki derajat pencapaian sebesar $66,77 \%$ dan termasuk kategori cukup. Pengguna website BPS Kab. Siak merasa cukup baik akan kemudahan yang diberikan untuk berkomunikasi dengan admin website.

\section{d) Pengaruh Kemudahan Penggunaan, Kualitas Informasi dan Kualitas Interaksi Layanan terhadap Kepuasan Pengguna.}

Untuk mengetahui besarnya pengaruh variabel kemudahan penggunaan, kualitas informasi dan kualitas interaksi layanan secara bersama-sama terhadap kepuasan pengguna website BPS Kab. Siak, dapat diketahui dengan menggunakan Uji F. Hasil pengujian yang diperoleh menunjukkan bahwa nilai koefisien determinasi antara variabel independen secara bersama-sama terhadap kepuasan pengguna adalah sebesar $63,80 \%$, sedangkan sisanya $36,2 \%$ merupakan sumbangan variabel lain yang tidak dikaji dalam penelitian ini.

Hasil uji $F$ analisis regresi berganda menunjukkan bahwa secara simultan variabel kemudahan penggunaan, kualitas informasi dan kualitas interaksi layanan berpengaruh positif dan signifikan terhadap kepuasan pengguna website BPS Kab. Siak. Meningkatkan secara bersama-sama kemudahan penggunaan, kualitas informasi, dan kualitas interaksi layanan dari website BPS Kab. Siak berarti dapat meningkatkan kepuasan pengguna.

Berapa besar pengaruh dari masing-masing variabel independen terhadap variabel dependen dapat dilihat pada Gambar 4.

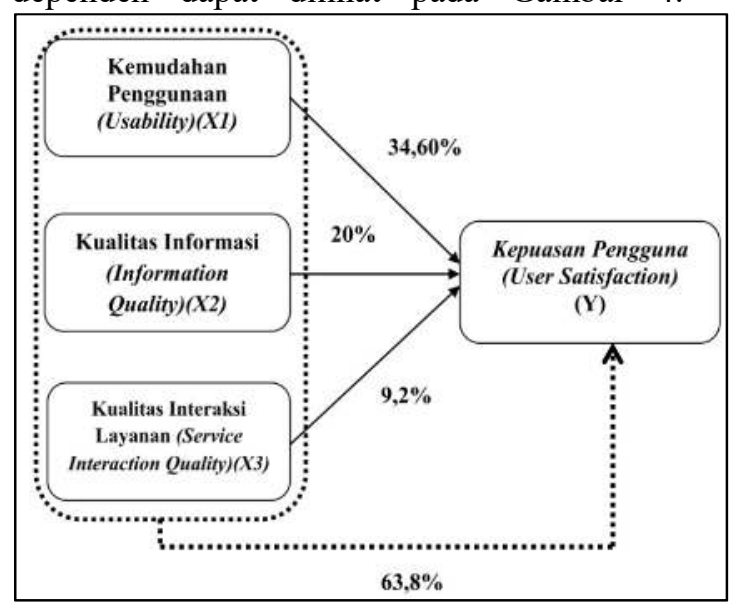

Gambar 4. Model Hasil Penelitian

\section{KESIMPULAN}

Hasil penelitian ini menunjukkan bahwa kemudahan penggunaan, kualitas informasi dan kualitas interaksi layanan, memberi pengaruh yang positif dan signifikan terhadap kepuasan pengguna, baik secara parsial maupun simultan. Ketiga variabel bebas tersebut memberikan kontribusi sebesar $63,80 \%$ terhadap kepuasan pengguna. Variabel 
kemudahan penggunaan memiliki kontribusi terbesar terhadap kepuasan pengguna, yaitu sebesar 34,6\%. Diantara variabel bebas lainnya, variabel kualitas interaksi layanan memiliki kontribusi paling kecil terhadap kepuasan pengguna yaitu sebesar 9,2\%. Hasil penelitian ini dapat diimplementasikan untuk meningkatkan kualitas website BPS Kab. Siak sehingga kepuasan pengguna juga meningkat.

\section{DAfTAR PUSTAKa}

1. BPS. Rencana Strategis Badan Pusat Statistik 2015-2019. Jakarta: BPS; 2015.

2. Juran JM. Juran on Leadership for Quality,The Free Press, MacMillan,Inc. E. Nugroho (penerjemah) Kepemimpinan Mutu. Jakarta: Pustaka Binaman Pressindo; 1989.

3. Christoper LdLKW. Manajemen Pemasaran Jasa. Indonesia: PT. Indeks; 2007.

4. Suyanto AH. Web Design Theory and Practices. Yogyakarta: Andi; 2007.

5. Hyejeong K, Linda S.N. The Impact of Website Quality On Information Quality, Value, and Loyalty Intentions In Apparel Retailing. Journal of Interactive Marketing. 2009.

6. Stuart J. Barnes RTV. An Integrative Approach to the Assesment of ECommerce Quality. Journal of Electronic Commerce Research. 2002;3:114-27.

7. Kotler P. Marketing Management, Internasional Edition. New Jersey: Prentice Hall.; 2003.

8. Tjiptono F. Pemasaran Jasa Edisi 1. Malang: Bayu Media Publishing; 2005.

9. Irawan H. 10 Prinsip Kepuasan Pelanggan. Jakarta: PT. Elex Media Komputindo; 2004.

10. Kotler P. Marketing Management: Analysis, Planning, Implementation and Control Millenium Edition. New Jersey: Prentice Hall Int, Inc.; 2000.

11. Sudjana. Teknik Analisis Regresi Dan Korelasi. Bandung: Tarsito; 1996.

\section{Biodata Penulis}

Nofirman, Mahasiswa Pascasarjana Fakultas Teknik Universitas Negeri
Padang. Lahir di Bukittinggi 2 November 1982. Menyelesaikan pendidikan sarjana pada Jurusan Matematika FMIPA dari Universitas Andalas Padang pada tahun 2006. 